\title{
UČNO E-OKOLJE SLOVENŠČINA NA DLANI: IZZIVI IN REŠITVE
}

\author{
Darinka VERDONIK, Simona MAJHENIČ, \\ Špela ANTLOGA, Sandi MAJNINGER, \\ Marko FERME, Kaja DOBROVOLJC
}

Fakulteta za elektrotehniko, računalništvo in informatiko, Univerza v Mariboru

Simona PULKO, Mira KRAJNC IVIČ, Natalija ULČNIK

Filozofska fakulteta, Univerza v Mariboru

Verdonik, D., Majhenič, S., Antloga, Š., Majninger, S., Ferme, M., Dobrovoljc, K., Pulko, S., Krajnc Ivič, M., Ulčnik, N. (2021): Učno e-okolje Slovenščina na dlani: izzivi in rešitve. Slovenščina 2.o, 9(1): 181-215.

DOI: https://doi.org/10.4312/slo2.0.2021.1.181-215

Prispevek izhaja iz treh izzivov, ki jih zaznavamo pri pouku slovenščine v višjih razredih osnovnih šol in v srednjih šolah: kako odpraviti napake knjižne norme, ki vztrajajo v pisnih izdelkih učencev; kako izboljšati frazeološko kompetenco; kako izboljšati sporazumevalno jezikovno zmožnost. Ti izzivi so osrednja točka razvoja sodobnega učnega e-okolja Slovenščina na dlani, ki temelji na jezikovnih in informacijsko-komunikacijskih tehnologijah ter prinaša podporo prožnim oblikam poučevanja, poučevanju na daljavo, lajša učiteljevo delo, omogoča pa tudi motiviranje učencev prek elementov igrifikacije. V prispevku predstavljamo zasnovo in izvedbo vsakega od štirih vsebinskih sklopov e-okolja: pravopis, slovnica, frazeologija in besedila.

Ključne besede: učenje slovenščine, računalniško podprto učenje jezika, e-učenje 


\section{UVOD}

Pojem prožne oblike poučevanja (po definiciji Evropske komisije) ${ }^{1}$ vsebuje učenje in poučevanje, ki je odzivno na potrebe učečega se ter njegove močne strani. ${ }^{2}$ Fleksibilno učenje učečemu se ponuja izbiro načina, okolja in časa učenja z namenom spodbujanja motivacije in vztrajnosti, lahko tudi v primerih, ko je prisotnost na lokaciji izvajanja učnega procesa otežena. Prožne oblike učenja in poučevanja tako omogočajo fleksibilno obliko dela, saj gre za sistem poučevanja in učenja, v katerem imajo učeči se možnost, da del učenja opravijo tudi izven šolskega okolja.

Digitalno okolje ponuja obetavna izhodišča za uresničitev prožnih oblik poučevanja, saj omogoča določeno stopnjo avtomatizacije, ki je lahko učitelju v pomoč pri spremljanju učenčevega napredka, učenca pa lahko delno samodejno vodi skozi učni proces. Z izzivom, kako s pomočjo digitalnega okolja podpreti prožne oblike poučevanja slovenščine v osnovnih in srednjih šolah, smo se spopadli v projektu Slovenščina na dlani. ${ }^{3}$

V prispevku predstavljamo učne izzive, ki jih zaznavamo pri pouku slovenščine v osnovnih in srednjih šolah, ter načine, kako se nanje odzvati z uporabo sodobnih jezikovnotehnoloških in informacijsko-komunikacijskih pristopov. V drugem poglavju predstavljamo pregled obstoječih e-pripomočkov za pouk slovenščine ter kako se mednje uvršča e-okolje Slovenščina na dlani. V tretjem poglavju opišemo pristopanje k problemu pravopisnih in slovničnih napak, ki so pri mnogih prisotne tudi še po koncu osnovnega in srednjega šolanja. $V$ četrtem poglavju navajamo, kako smo se lotili spoznavanja frazemov in pregovorov ter izboljšanja frazeološke kompetence med mladimi. V petem poglavju predstavimo pripravo sklopa nalog za boljšo sporazumevalno jezikovno

1 Definicija je dostopna na spletni strani: https://www.igi-global.com/dictionary/ flexible-learning/11249.

2 Odpiranje izobraževanja: inovativno poučevanje in učenje za vse z novimi tehnologijami in prosto dostopnimi učnimi viri https://eur-lex.europa.eu/legal-content/SL/TXT/ PDF/?uri=CELEX:52013DC0654\&from=HU.

Strateški okvir - Izobraževanje in usposabljanje 2020: http://ec.europa.eu/education/ policy/strategic-framework_sl.

3 Projekt sofinancirata Republika Slovenija in Evropska unija iz Evropskega socialnega sklada. Izvaja se na Filozofski fakulteti, Pedagoški fakulteti in Fakulteti za elektrotehniko, računalništvo in informatiko Univerze v Mariboru. 
zmožnost, in sicer tvorjenje ter razumevanje večpredstavnostnih klasičnih ali elektronskih pisanih in govorjenih besedil. $V$ šestem poglavju na enem mestu predstavimo programiranje in vrednotenje vaj ter izdelavo razlag $\mathrm{k}$ vajam.

\section{RAČUNALNIŠKO PODPRTO UČENJE JEZIKOV IN UČNA E-GRADIVA ZA SLOVENŠČINO}

$\mathrm{Z}$ računalniki podprto učenje jezikov (angl. computer assisted language learning - CALL) ima začetke že v šestdesetih letih 20. stoletja (Davies, 2016); z razširitvijo osebnih računalnikov v sedemdesetih letih je dobilo precejšen zagon, a je bilo sprva omejeno na vnaprej sprogramirana navodila ter je bilo videti kot vnaprej posnet in sprogramiran linearni jezikovni laboratorij. S prelomno objavo Higginsa in Johnsa (1984) je bil predstavljen nabor novih možnosti za alternativne načine uporabe računalnikov pri učenju jezika; razdeljen je bil v štiri skupine: (1) sledenje navodilom (angl. do what I tell you), pri katerem računalnik uporabniku pove, kaj mora narediti (vaje z izbiranjem, vpisovanjem, kvizi ...); pri tem ni zanemarljivo, da učenca ne zanima samo, ali in zakaj je nekaj narobe, ampak tudi, zakaj je nekaj pravilno, kar pomeni, da je nujno tudi vključevanje razlag; (2) ugibanje (angl. guess what was there), pri katerem računalnik izbriše del besedja/besedila, uporabnik pa mora ugotoviti, kaj se je tam nahajalo; (3) računalnik kot pomagalo (angl. can I help you?), kjer lahko učitelj pri učenju jezika na inovativne načine uporablja obstoječa računalniška orodja, kot so tezavri, slovarji sopomenk, konkordančniki; (4) računalniške simulacije (angl. how do I get out of this?), kamor sodijo razne igre, sestavljanke (npr. sestavljanje besed iz ponujenih črk, delov besed) ipd.

Danes lahko računalniško podprto učenje jezika ločimo glede na načine uporabe računalnika (Davies, 2016). Prvi se nanaša na računalniško okolje, sprogramirano namensko za učenje in utrjevanje jezikovnih vzorcev ali za prepoznavanje in popravljanje uporabnikovih napak. Drugi se nanaša na raziskovanje jezika, pri čemer so pogosto uporabljeno orodje različni konkordančniki in drugi jezikovni viri. Tretji način se nanaša na multimedijsko podprto učenje jezika prek avdio ali video vsebin, ki so pogosto pripravljene tako, da uporabnika vodijo pri učenju jezika (npr. zgoščenke za učenje tujega jezika). Sem lahko sodijo tudi razpoznavalniki govora, ki uporabniku pomagajo odpravljati težave pri branju ali govorjenju v tujem jeziku. Zadnji, četrti način se nanaša 
na možnosti učenja jezika, ki jih odpira internet, zlasti z različnimi virtualnimi učilnicami, uporabo posnetkov z Youtuba ipd.

Računalniško podprto učenje se je večinoma razvijalo v povezavi z usvajanjem tujega jezika. V povezavi z učenjem o jeziku (materinščini) pa je ob tem prav tako nastajalo veliko elektronskih učbenikov ali delovnih zvezkov. Učitelji slovenščine tako lahko pri pouku slovenščine uporabljajo kar nekaj različnih e-gradiv in okolij. Založba Rokus svoje učbenike, berila in delovne zvezke ponuja tudi v e-obliki. Za prvo triletje osnovne šole je na voljo izobraževalni portal Lilibi, ${ }^{4}$ ki vključuje tudi slovenščino. Za četrti in peti razred ponuja učno serijo Radovednih pet, ki poudarja medpredmetno povezovanje. Vključuje interaktivne samostojne delovne zvezke, interaktivne učbenike in interaktivno berilo. Interaktivno gradivo v napredni obliki je obogateno z videoposnetki, animacijami, interaktivnimi vajami in drugimi dodatki. Celotna serija Rokusovih gradiv je zamišljena na principu t. i. kombiniranega učenja, tj. prepletanja tiskanih in interaktivnih komponent. Založba Mladinska knjiga trži portal UČIMse, ${ }^{5}$ ki ponuja interaktivne, grafično oblikovane in igrificirane vaje za celotno osnovno šolo, v posebnem sklopu za razredno stopnjo od 1. do 5 . in v posebnem sklopu za predmetno stopnjo od 6. do 9. razreda. Portal Devetka ${ }^{6}$ predstavlja zbirko spletnih nalog, $v$ kateri najdemo povezave na različne ponudnike raznovrstnih e-gradiv. Za slovenščino najdemo zelo različne vsebine, od nacionalnih preverjanj znanja do posameznih vaj ali pripomočkov, ki so jih objavili različni avtorji. Na javno financiranem portalu iUčbeniki so pod prosto licenco Creative Commons na voljo interaktivni učbeniki za slovenščino za 8. in 9. razred osnovnih šol in prvi letnik gimnazij. Podobne vrste so tudi e-gradiva Projekta slovenščina, ${ }^{8}$ ki so na voljo za 8. razred osnovnih šol in 2. letnik srednjih šol ter gimnazij. Portal Interaktivne vaje ${ }^{9}$ vsebuje povezave na interaktivne vaje, tudi iz slovenščine, za celotno osnovno šolo. Nekatere vaje so narejene v okviru portala, pogosto pa nas portal samo preusmeri na drug

\footnotetext{
4 https://www.lilibi.si/

5 https://www.ucimse.com/

6 http://devetka.net

7 http://eucbeniki.sio.si

8 http://www.s-sers.mb.edus.si/gradiva/w3/slo8/ooo_mapa/index.html

9 https://interaktivne-vaje.si/index.html
} 
spletni naslov, kjer so vaje na voljo. Pedagoški slovnični portal ${ }^{10}$ obravnava teme, ki šolarjem povzročajo največ težav pri pisanju. Izbrana poglavja celostno obdela, od razlage prek primerov do vaj. Ta portal je prvi v slovenskem okolju, ki izkorišča korpuse in korpusne pristope za definiranje tem, oblikovanje razlag in pripravo raznovrstnih vaj za izbrane teme. Temelji na skrbno premišljenem in izvedenem metodološkem postopku (Rozman idr., 2020), pokriva pa manjši del slovničnih problemov.

Navedeni pregled kaže, da med pregledanimi gradivi prednosti digitalnega formata v največji meri izkoriščajo na portalu UČIMse, saj uporabljajo bogato animacijo, grafiko in zvočne učinke; izkoriščen je element igrifikacije, ki vključuje virtualno okolje, nagrajevanje, vodenje skozi vaje z animiranimi junaki ipd. Zelo dobro grafično animacijo in igrifikacijo izkorišča tudi večina vaj, ki so na voljo prek spletnega portala Interaktivne vaje. Pomemben korak naprej pri izrabi potencialov digitalnega medija pa predstavlja tudi Pedagoški slovnični portal. Nabor e-vsebin za učenje slovenščine je v pregledanih gradivih sicer dokaj širok, vendar večinoma osredotočen na osnovno šolo ali celo na razredno stopnjo, za srednje šole je gradiv veliko manj. Opazno je, da se pogosto uporabljajo animacija, grafika, video vsebine in igrifikacija, ni pa še omogočene avtomatizirane individualizacije v smislu, da bi se vsebina in zahtevnost vaj samodejno prilagajali znanju učečega se. Uporabnik se mora tako v veliki količini razpoložljivih vsebin znajti sam ali pa ga mora skoznje voditi učitelj, ki pa ima prav s prilagajanjem dela vsakemu učečemu se največ težav in v tem segmentu potrebuje največ podpore. Osnovni poudarki novega e-okolja Slovenščina na dlani, ki ga predstavljamo, so zato: (1) obravnavanje vsebin, ki se usvajajo v višjih razredih osnovne šole in v srednji šoli, (2) samodejno prilagajanje vaj potrebam učečega se in (3) olajšanje učiteljevega dela pri formativnem spremljanju napredka posameznikov.

\section{3}

POGOSTE PRAVOPISNO-SLOVNIČNE NAPAKE PRI PISANJU

Dva od štirih vsebinskih sklopov e-okolja Slovenščina na dlani se nanašata na napake, ki se pri mnogih tudi še po koncu osnovnega in srednjega šolanja pojavljajo pri pisanju besedil. Na vrsto tovrstnih napak so opozarjali tudi učitelji, sodelujoči v projektu, nekatere pa izpostavljajo tudi strokovnjaki v

10 http://slovnica.slovenscina.eu/ 
strokovnih objavah, razpravah in priročnikih (Križaj in Bešter Turk, 2018; Gomboc, 2019).

\subsection{Vsebinska področja iz pravopisa in slovnice}

Pri definiranju tem in vsebin s področja pravopisa in slovnice smo se v projektu oprli na analizo napak v korpusu Šolar (Rozman idr., 2020), ki so jo predstavili Kosem idr. (2012). Na podlagi te analize in na podlagi napak, na katere so opozarjali sodelujoči učitelji, smo definirali vsebinska področja iz pravopisa in slovnice, ki jih obravnavamo v učnem e-okolju. Pri tem smo upoštevali, da lahko napake oz. odstopi od norme nastajajo zaradi: (1) nepoznavanja pravopisnih in slovničnih pravil učečega se, zato ga $\mathrm{v}$ navodilih $\mathrm{k}$ nalogam usmerjamo k prepoznavanju pravilnega oz. napačnega zapisa, kar je smiselno ovrednoteno s točkami za pravilni odgovor; (2) neustrezne jezikovne izbire glede na zvrst, zato ga $\mathrm{v}$ navodilih $\mathrm{k}$ nalogam usmerjamo k prepoznavanju najprimernejšega oz. najustreznejšega zapisa, za kar bo učeči se s točkami nagrajen šele, ko prepozna najustreznejši zapis; (3) rahljanja jezikovne norme (npr. bodo vs. bojo), zato ga v navodilih k nalogam usmerjamo npr. k prepoznavanju pogovorne oblike zapisane besede.

Za pravopis te vsebine vključujejo:

- uporabo ločil: končna ločila (vprašaj, tri pike), nekončna ločila (problematiko postavljanja vejice, in sicer pri podredjih - predmetni, osebkov, časovni, krajevni, načinovni, vzročni, pogojni, dopustni in prilastkov odvisnik; pri priredjih - vezalno, stopnjevalno, protivno, ločno, posledično ter pojasnjevalno in sklepalno priredje; pri zahtevnejših primerih z vezniki ter pri pastavkih, pristavkih in vrivkih; pomišljaj; tri pike) in ločila pri premem govoru;

- uporabo velike in male začetnice pri pridevnikih na -ski in -ški ter -ov in -ev, pri naselbinskih in nenaselbinskih imenih, pri pisanju imen bitij ter pri stvarnih imenih;

- pisanje skupaj oz. narazen, in sicer pri veznikih, predlogih in členkih, glagolih, pridevnikih, prislovih in zvezah z njimi, pri samostalnikih, zaimkih, števnikih in pri okrajšavah; v tem sklopu je obravnavano tudi pisanje z vezajem; 
- zahtevnejše primere zapisa, ki se nanašajo na zapis prevzetih besed, zapis sklopov z neobstojnim in vrinjenim samoglasnikom, zapise $\mathrm{s}$ podvojenimi črkami, zapise s sičniki, z zvočniki in $u$ ter t. i. besede nagajivke (npr. stremeti vs. strmeti).

Za slovnico te vsebine vključujejo:

- težave pri pisanju, povezane s samostalniki, in sicer upoštevanje preglasa pri sklanjanju, sklanjanje lastnih imen, zahtevnejše primere sklanjatev (npr. mati, hči, gospa, možje, človek, starši), zanikani rodilnik;

- rabo pridevnikov: določna in nedoločna oblika, stopnjevanje ter knjižna raba svojilnih pridevnikov iz lastnih imen (npr. Markov vs. Markotov);

- rabo glagolov: dvojinske oblike, oblika sedanjika (npr. bodo vs. bojo), prihodnjika (npr. boš vs. boš bil) in preteklega deležnika (npr. odločil vs. odloču), ujemanje osebka s povedkom, uporaba namenilnika, nedoločnika in kratkega nedoločnika, uporaba glagolov morati in moči ter vedeti in znati, uporaba vikanja;

- rabo zaimkov: oziralni zaimek (npr. ki vs. kateri), svojilni in povratno svojilni zaimek, ujemanje zaimka (npr. z njim vs. $z$ njem), zaimek v dvojini (problem opuščanja dvojine), zaimek v mestniku ali dajalniku (npr. njem vs. njemu) in zaimek v rodilniku (npr. je vs. jo);

- rabo predlogov: čez, do, na, nad, poleg, pri, skozi ter $h, i z, k, o, s, v, z$ in $z a \mathrm{v}$ kontekstih, kjer se pogosto uporabljajo manj ustrezni ali neustrezni predlogi (npr. pregovori okrog ljubezni vs. pregovori o ljubezni);

- rabo veznikov: enodelni in enobesedni vezniki (npr. in, ter, pa; temveč, marveč, ampak, vendar; ne in brez); dvodelni in večbesedni vezniki; vsebine so usmerjene v utrjevanje ustreznih vzorcev rabe v kontekstih, kjer učitelji pogosto opažajo neustrezno izbiro veznikov (npr. Odklonil je tako kosilo in večerjo);

- besedni red: zaporedje stavčnih členov (npr. veznik ker + pomožni glagol + glagol/samostalnik/prislov/zaimek: Predvsem zato, ker smo prireditev prestavili s torka na soboto vs. Predusem zato, ker 
prireditev smo prestavili s torka na soboto) in naslonski niz (npr. zaporedje da naj se).

\subsection{Postopek izdelave nalog za vsebine iz pravopisa in slovnice}

Pri obravnavi vsebin iz pravopisa in slovnice smo izhajali iz namere, v čim večji meri izkoristiti jezikovnotehnološke pristope in metode za pripravo učnega e-okolja. Strateško smo sledili principu »od prakse k teoriji«, kar pomeni, da učenci ob vajah prepoznavajo, kje jim slabo poznavanje pravopisnih in slovničnih vzorcev ter pravil knjižne norme povzroča težave pri pisanju, da z dodatnimi vajami utrjujejo predvsem ta področja in da ob tem hkrati spoznavajo tudi razlage in razloge, ki stojijo za posameznimi pravili knjižne norme. Pri tem smo v veliki meri izhajali iz rezultatov Pedagoškega slovničnega portala (Rozman idr., 2020; Kosem idr., 2012), a je med obema tudi nekaj ključnih razlik: (1) v e-okolju Slovenščina na dlani je poudarek na obravnavi velike količine različnih pravopisnih in slovničnih tem, posledično ni bila narejena podrobna dodatna jezikoslovna analiza posameznih tem, ampak smo se opirali na obstoječe jezikoslovne priročnike; (2) v ospredju so vaje: učeči se vstopa v e-okolje skozi vaje, razlagam je posvečene manj pozornosti; (3) učeči se je avtomatsko voden skozi e-okolje, ni se mu treba odločati, katere vaje bo delal; (4) e-okolje je prilagojeno učiteljem in jim omogoča vodenje in spremljanje učečih se ter komunikacijo z njimi.

Postopek izdelave velike količine vaj za vsebine, predstavljene v poglavju 3.1, je bil izveden po naslednjih korakih:

1. priprava korpusnega gradiva, ki bo osnova za priklic velike količine avtentičnih primerov za vsako vajo - korpus MAKS;

2. definiranje vaj z didaktičnega in jezikoslovnega vidika;

3. priklic primerov za vsako vajo iz zbranega korpusa, oblikovanje baze primerov in ročni pregled primerov;

4. programiranje vaj, omogočanje interaktivnega reševanja vaj in vzpostavitev hranjenja uporabnikovih odgovorov;

5. definiranje in izdelava algoritmov za vrednotenje uporabnikove uspešnosti reševanja vaj;

6. izdelava razlag $\mathrm{k}$ vsebinam vaj. 
Posamezne korake predstavljamo v nadaljevanju. Korake programiranja in vrednotenja vaj ter izdelave razlag opisujemo v zadnjem delu članka za vse vsebinske sklope e-okolja skupaj.

\subsection{Priprava korpusnega gradiva - korpus MAKS}

Korpus MAKS (akronim za MlAdinski KorpuS) obsega pribl. 10 mio. besed oz. pribl. 12 mio. pojavnic. Dobro polovico tega sestavljajo besedila iz mladinskega in drugega leposlovja ali priročnikov. Dobrih 40 \% besedil je zajetih iz publicistike, manjši delež, dobrih 300.000 besed, pa s spleta. Besedilodajalci ${ }^{11}$ so bili večinoma založbe, posamezni leposlovni avtorji, kar nekaj besedil pa je bilo prevzetih tudi iz korpusa Gigafida (Logar Berginc idr., 2012).

Vsa zajeta besedila so bila ročno pregledana; preverjeno je bilo, ali po vsebini (vsebina ni oglasna, ideološko zaznamovana, nasilna, spolna, zelo strokovna in težko razumljiva ipd.) in jezikovno (rabljen je knjižni jezik) ustrezajo specifičnim potrebam e-okolja Slovenščina na dlani. Pokazalo se je, da so vsebine, ki za učeče se niso primeren vir povedi za vaje iz pravopisa in slovnice, zelo pogoste: v leposlovju, zlasti nemladinskem, so bile pogoste vsebine, povezane z nasiljem, občasno pa smo morali vsebine izločati tudi zaradi slenga, vulgarizmov, narečnega ali starinskega jezika. $V$ publicistiki so se po drugi strani pojavljale propagandne ali ideološko zaznamovane vsebine, občasno pa tudi jezikovno nezadostno pregledana besedila. Zahtevnim strokovnim vsebinam smo se skušali izogniti že pri izboru virov.

Ob pregledu smo besedilom ročno pripisali vir, leto objave, naslov, avtorja, primernost za osnovno ali srednjo šolo ter teme, vsa besedila pa smo nato strojno označili še z vidika oblikoslovja, skladnje in imenskih entitet. Za oblikoslovno in skladenjsko označevanje smo za čim večjo natančnost pripisanih oznak vzpostavili delotok, ki združuje več različnih splošno uporabljenih orodij za slovenščino, in sicer orodje Obeliks4J (Grčar idr., 2012) za segmentiranje besedil na besede in povedi, orodje ReLDI (Ljubešić in Erjavec, 2016) za lematizacijo besed ter orodje Stanford Parser V3 (Qi idr., 2018) za pripisovanje oblikoslovnih oznak po sistemu JOS (Erjavec idr., 2010) ter skladenjskih oznak po sistemu Universal Dependencies (Nivre idr., 2016). Na koncu smo z orodjem Janes NER (Fišer idr., 2018) izvedli še označevanje

11 Navedeni so na spletni strani projekta http://projekt.slo-na-dlani.si/. 
imenskih entitet $\mathrm{v}$ besedilu. Vsa orodja so bila naučena na učnem korpusu ssj50ok (Krek idr., 2019).

\subsection{Definiranje vaj}

Za vsako temo iz pravopisa in slovnice smo definirali vaje. Pri tem smo bili pozorni, da so bile pri vsaki temi vaje različnih tipov in zahtevnostnih stopenj.

Vaje smo definirali v več korakih, in sicer smo za vsako vajo določili identifikacijsko številko, temo, h kateri sodi, zahtevnostno stopnjo, tip naloge, navodila za programiranje priklica primerov in načina reševanja ter navodilo za uporabnika.

Pri nekaterih tipih vaj je bilo treba poleg teh elementov pripraviti še nekatere dodatne. Za poseben tip vaje, ki od učečega se zahteva, da svojo izbiro odgovora utemelji, smo pripravili predloge pravilnih in napačnih utemeljitev, pri čemer smo upoštevali različne priklicane primere, ob katerih se bodo lahko prikazale. Primer take vaje je, ko mora uporabnik odgovoriti, ali je vejica ob večbesednem vezniku pravilno uporabljena ali ne. $V$ drugem koraku mora uporabnik pravilno dopolniti vnaprej definirano utemeljitev odgovora: Med deli večbesednega enodelnega veznika se vejica ${ }^{* * *}$, pri čemer lahko izbira med piše in ne piše.

Za posamezne vaje je bilo treba izdelati seznam ustreznih besednih kandidatov, tj. besed, besednih zvez ali daljših kolokacijskih nizov, na podlagi katerih so bili priklicani primeri. Kot vire za iskanje ustreznih besednih kandidatov smo uporabili: korpus MAKS, korpus Gigafida, druge relevantne jeziko(slov) ne vire (SSKJ, Slovenska slovnica, jezikoslovne razprave) ali nejeziko(slov)ne vire (Wikipedija, enciklopedije ipd.). Glavna vodila so bila razumljivost, aktualnost, frekventnost iskanih kandidatov in možnost čim bolj nazorne in realistične ponazoritve problematike konkretne vaje oziroma prikaz dejanske jezikovne rabe. Načeloma so vse enote na seznamih v lematizirani obliki, razen kadar je za priklic ustreznega primera potrebna točno določena skladenjska oblika (npr. tekem, dekel, oken pri preverjanju zapisa neobstojnega samoglasnika v množinski rodilniški obliki).

Oblikovanje seznamov besednih kandidatov za priklic primerov je potekalo na štiri načine, in sicer: 
(1) na podlagi nekorpusnih virov, npr. za iskanje primerov zaključenega nabora besed ali besednih zvez, ki so relevantne za preverjanje določene vsebine pri nalogi in so že popisane v jezikovnih priročnikih (pri nalogi, ki preverja sklanjanje zaimkov kaj, malokaj, marsikaj, mnogokaj in nekaj, natančneje njihovo rodilniško in tožilniško obliko, so ustrezni primeri priklicani iz nabora vseh iskanih zaimkov v rodilniški obliki, kot napaka pa so v priklicane primere vstavljeni njihovi pari s seznama v tožilniški obliki) ali drugih pisnih in spletnih virih (za nabor besednih kandidatov za priklic primerov pri preverjanju začetnice imen praznikov smo uporabili relevantne spletne strani z informacijami javnega značaja, ${ }^{12}$ Wikipedijo ipd.);

(2) na podlagi korpusa MAKS z iskanjem preko posebnega spletnega vmesnika (konkordančnika) NoSketch Engine; ${ }^{13}$

(3) z združevanjem nekorpusnih virov in korpusa MAKS, tako da smo najprej pripravili model v obliki popisa ustreznih jezikovnih zakonitosti iskanih besednih kandidatov, ki je nato v drugi fazi služil za luščenje relevantnih zadetkov v korpusu MAKS, npr. za iskanje samostalniških (po podobnem principu tudi glagolskih, pridevniških) sestavljenk (in tudi nekaterih drugih besedotvornih vrst) smo oblikovali seznam potencialnih predponskih obrazil (nad-, pod-, anti-, pra-, raz-, super-, eks-, ultra-, ne-, a-, proti- itd.), v drugi fazi pa smo v korpusu MAKS poiskali tiste leme, ki so sestavljene iz take predpone in nekega drugega znanega samostalnika (npr. po seznamu iz Sloleksa): pod + odbor, anti + oksidant itd.;

(4) s paberkovanjem, npr. za priklic primerov, ki preverjajo bodisi poznavanje razlikovanja med zapisom in pomenom določenih besednih parov bodisi stopnjo podomačitve določene prevzete besede (glagoli ustaviti - vstaviti, uročiti - vročiti; ${ }^{*}$ coca-cola - ${ }^{*}$ koka kola - kokakola itd.).

Skupaj sta bila za naloge pri vsebinskih sklopih pravopis in slovnica pripravljena 102 seznama besednih kandidatov.

12 https://www.gov.si/teme/drzavni-prazniki-in-dela-prosti-dnevi/

13 https://www.clarin.si/noske/ 
Vaje smo razdelili v tri zahtevnostne stopnje: osnovna, srednja in zahtevna. Na osnovni stopnji uporabnik prepoznava napake (npr. z izbiranjem, iskanjem, označevanjem (ne)pravilnega odgovora). Pri srednje zahtevnih nalogah mora uporabnik napake ne samo prepoznati, ampak tudi odpraviti (npr. s popravljanjem, premikanjem, vstavljanjem). Najzahtevnejše naloge pa od uporabnika zahtevajo tudi, da ve, zakaj je neka rešitev pravilna ali napačna.

Skupno smo definirali več kot 500 različnih vaj in za vsako smo v naslednjem koraku priklicali primere iz korpusov.

\subsection{Priklic primerov za vaje}

Po jezikoslovno-didaktičnem definiranju vaj, opisanem v razdelku 3.4, so bila za vsako vajo oblikovana še podrobnejša jezikovnotehnološka navodila za samodejni priklic vseh konkretnih primerov rabe obravnavanih jezikovnih pojavov v korpusu, najpogosteje v obliki zaključenih povedi. Pri nekaterih vajah so ta navodila zelo preprosta, saj se opirajo zgolj na obliko besed ali besednih zvez (npr. iskanje pojavnic z nizom števk in/ali črk, vezajem in nizom malih črk za priklic vseh povedi z zvezo podstave in končaja, kot so 7o-letni, LDS-ov, a-jevski) ali na vnaprej pripravljene sezname, omenjene v razdelku 3.4 (npr. priklic vseh povedi, v katerih se kot neprva pojavnica pojavi lema s seznama zemljepisnih lastnih imen na -sko/-ško;-ska/-ška, npr. Dogodki na Koroškem so ga pretresli.). Za veliko večino vaj pa se je bilo treba za priklic ustreznih primerov opreti tudi na višje ravni označenosti korpusa, kot so oblikoslovne oznake (npr. iskanje neprvih pojavnic z veliko začetnico in oznako za osebni ali svojilni zaimek v drugi osebi za priklic povedi s spoštljivimi ogovori, npr. Vabimo Vas, da se nam pridružite), skladenjske oznake (npr. za priklic povedi s posameznimi tipi stavkov) ali njihove kombinacije (npr. iskanje nedoločnih oblik pridevnikov moškega spola ednine v vlogi povedkovega določila za priklic vseh relevantnih povedi za vaje o rabi nedoločnih pridevniških oblik, npr. Šopek je lep). Zaradi bogate označenosti korpusa MAKS, zlasti na ravni skladnje in imenskih entitet, kakršne drugi referenčni korpusi za slovenščino še nimajo, je bilo tako mogoče samodejno priklicati tudi korpusne primere za skladenjsko kompleksnejše slovnične in pravopisne pojave.

Ker vaje znotraj posameznih tematskih sklopov pogosto vsebujejo enake jezikovne pojave (npr. glavni stavek, odvisnik, veznik za načinovno podredje, 
priredna zloženka, stični pomišljaj), temelj jezikovnotehnoloških navodil za priklic primerov $\mathrm{k}$ vajam predstavlja seznam tovrstnih jedrnih gradnikov, ki jih mora računalnik razpoznati, da lahko sestavi programsko predstavitev problema. Znotraj učnega e-okolja smo formalno definirali več kot 300 gradnikov, navodila za priklic primerov k posamičnim vajam pa temeljijo na njihovih različnih kombinacijah.

Po opredelitvi gradnikov je bilo treba definirati način njihovega združevanja, pri čemer je bil uporabljen enostaven domensko specifični jezik z osnovnimi logičnimi pravili in parametri za zapis pravil izbire primerov. Zapis pravila tako omogoča osnovne logične operacije, kot so in, ali in ne za združevanje gradnikov v kompleksno pravilo, vsakemu gradniku pa je mogoče pripisati še specifične parametre, pri čemer je najpogosteje uporabljen parameter število ponovitev gradnika z operatorji večje, manjše in je enako (npr. 'poved z vsaj enim odvisnikom' ali ‘poved z največ enim stičnim pomišljajem'). Izdelan je bil uporabniški vmesnik za zapis takšnih pravil in interpreter, ki na podlagi pravil prikliče ustrezne primere povedi iz korpusa MAKS. Za vsako posamezno vajo so bila ustvarjena pravila povezovanja gradnikov, na podlagi katerih je interpreter priklical vse ustrezne povedi. Za njihovo pregledovanje je bil izdelan poseben uporabniški vmesnik, v katerem smo kandidate ročno pregledali in z izločanjem neustreznih primerov oblikovali končno množico povedi, iz katerih se v učnem e-okolju tvorijo vaje.

Iz izbranih povedi je bilo treba v naslednjem koraku izdelati ustrezno podatkovno strukturo, ki poleg pravilno izbranega primera pripravi vsebino vaje. Struktura je odvisna od tipa vaje, pri čemer ločimo vaje, (1) kjer je uporabniku treba ponuditi poved, v kateri določen del manjka in ga mora dopolniti, (2) kjer je določen del povedi spremenjen in se mora do nje opredeliti, (3) kjer mu je potrebno ponuditi več povedi, on pa mora izbrati pravilne, in (4) kjer mu je ponujeno več delov različnih povedi, on pa jih mora ustrezno povezati. Prvi korak v takšnih spremembah je vedno določanje dela povedi, ki bo spremenjen. Za navedeno je bil izdelan domensko specifičen jezik, ki uporablja izdelane gradnike in njihove parametre. Slednji omogoča, da z njim označimo del povedi, ki bo spremenjena, in tudi zapišemo vrsto spremembe. Te so lahko preproste, kadar samo izbrišemo oziroma zakrijemo besedo ali del besede, ali pa kompleksne, kadar je treba za uporabnika pripraviti nepravilne primere, ki 
pa morajo delovati verodostojno. V slednjih primerih gre največkrat za zamenjavo dela originalne besede, celotne besede ali skupine besed. Spremembe so lahko preproste, kot prestavitev mesta vejice, zamenjava velike začetnice ali menjava končnice v nedoločniku, ali kompleksne, kjer je določeno besedo treba zamenjati s pomensko sorodno besedo, v istem sklonu, spolu in številu, kot je to v primeru menjave besed vedeti in znati. Za slednje smo uporabili Sloleks 2.o (Dobrovoljc idr., 2015), kjer smo iz osnovne oblike, ki je podana v pravilih za spremembe, na podlagi oblikoslovnih oznak besede, ki jo želimo zamenjati, dobili ustrezno izpeljanko. Izdelan je bil interpreter, ki iz pravil sprememb in potrjenih primerov pri posamezni vaji izdela zapis primerov v obliki JSON, ta pa se nato uporabi za prikaz vaj v uporabniškem vmesniku, njihovo reševanje in tudi vrednotenje. Z navedenimi orodji je v učno e-okolje mogoče dodajati tako nove primere kot tudi nove vaje.

\section{POZNAVANJE FRAZEMOV IN PREGOVOROV}

Eden izmed izzivov pri pripravi učnega e-okolja je bil, kako prispevati k spoznavanju frazemov in pregovorov ter s tem k izboljšanju frazeološke kompetence med mladimi. Znano je sicer, da nabor frazeoloških enot, ki jih poznamo in razumemo, narašča s starostjo (prim. Meterc, 2019), vendar pa osnovno- in srednješolski učitelji slovenščine menijo, da bi bilo koristno frazeologiji nameniti nekoliko več pozornosti, saj si, kot opažajo, učenci oz. dijaki »pogosto napačno interpretirajo frazeme« (Voršič, 2018, str. 91). Težave jim torej povzroča razumevanje enot, kar nadalje vodi v negotovost pri rabi. Poseben problem predstavlja tudi dejstvo, da v slovenskem prostoru še ni na voljo priročnika, ki bi se posebej posvečal slovarski obravnavi frazeoloških enot in bi bil prilagojen šolajoči se populaciji. ${ }^{14}$ Naš namen je bil v e-okolju ponuditi raznovrstne vaje, ki bodo pomagale pri spoznavanju teh aktualnih in učinkovitih jezikovnih sredstev, s katerimi se začnemo srečevati že v zgodnjem otroštvu in ki pomembno sooblikujejo naše sporazumevanje na različnih področjih (Jesenšek, 2018).

14 Novost na tej ravni je slovar pregovorov in sorodnih enot, ki je od konca leta 2020 na voljo na portalu Fran (prim. Meterc, 2020). 


\subsection{Vsebinska področja}

S sklopom, vezanim na frazeme in pregovore, smo želeli izpostaviti vsebine, ki so nekoliko manj prisotne v učnih načrtih, ${ }^{15}$ kljub temu pa so za osnovno- in srednješolce zelo zanimive in motivirajoče. Sledili smo trem ciljem: (1) pripraviti slovarske opise izbranih frazemov in pregovorov, (2) zasnovati raznovrstne vaje ter (3) vaje podpreti z nazornimi teoretičnimi razlagami, ki bodo služile kot pomoč pri reševanju. Osredinili smo se na frazeme kot osnovne frazeološke enote in na pregovore, ki jih umeščamo k frazeologiji v širšem smislu. V prvi fazi smo pripravili izbor sto frazemov in sto pregovorov (prim. Ulčnik, 2019; Ulčnik in Meterc, 2019), pri čemer smo izhajali iz treh osnovnih kriterijev: (1) aktualnost enot, (2) didaktična relevantnost enot, (3) pokrivanje različnih tematskih skupin. Aktualnost enot smo vezali na prisotnost v učbeniških gradivih (pomeni, da obstaja velika verjetnost, da se s temi enotami srečajo pri pouku slovenščine), ${ }^{16}$ pri čemer so bili frazemi in pregovori izpisani iz izbranih gradiv založb Mladinska knjiga in DZS (npr. iz delovnih zvezkov in beril od 6. do 9. razreda in od 1. do 4. letnika), in na zadostno pogostost v korpusu sodobnih pisnih besedil Gigafida v. 2.0 Dedup (Krek idr., 2019); enote, ki so v korpusu imele le posamične zglede rabe, niso bile upoštevane. ${ }^{17}$ Pri frazemih je poseben problem predstavljalo dejstvo, da v slovenskem prostoru nimamo veliko raziskav o poznavanju in pogostosti rabe frazemov oz. nimamo seznamov (naj)pogostejših enot, medtem ko smo pri pregovorih lahko izhajali iz t. i. paremiološkega optimuma oz. seznama tristo najbolj poznanih in uporabljanih enot (prim. Meterc, 2017). Kot didaktično relevantne smo opredelili tiste enote, pri katerih je (praviloma zaradi višje stopnje idiomatičnosti) izkazano oteženo razumevanje. Pri tem smo upoštevali konkretne predloge učiteljev; ti so izpostavili frazeme in pregovore, za katere so opazili, da jih učenci in dijaki slabše poznajo oz. jih ne razumejo, npr. gordijski

15 Kržišnik (2015, str. 132) pri tem ugotavlja, da so zlasti na srednješolski ravni učni načrti vsebinsko že bolj natančni, kot so bili npr. pred tridesetimi leti, in omogočajo boljši vpogled v seznanjanje s frazeologijo.

16 Več o gradivu in poteku analize v Ulčnik, 2019; Ulčnik in Meterc, 2019.

17 Iz gradiva je bil na primer izpisan frazem luna trka koga, ki na koncu ni bil izbran, saj ima v korpusu manj kot deset pojavitev. Preverjanje v korpusu je sicer potekalo na podlagi t. i. fraznih jeder, da bi lahko v čim večji meri zajeli variantnost enot, npr. bojen sekira za iskanje frazema zakopati bojno sekiro; za pridobivanje variant smo uporabljali tudi iskanje v okolici (bojna sekira - zakopati/zakopan/izkopati/izkopan). 
vozel, labodji spev, posuti se s pepelom, priti z dežja pod kap, vleči dreto. Tretji kriterij se je nanašal na idejo o vključevanju frazemov in pregovorov iz različnih tematskih skupin, s čimer smo želeli izpostaviti, da se frazeološke enote pojavljajo na različnih semantičnih poljih; z njimi lahko spregovorimo o človeku (npr. stisniti zobe, videz vara), medosebnih odnosih (npr. pogledati skozi prste, obljuba dela dolg), dejavnostih in bivanju (npr. dobiti zeleno luč, vaja dela mojstra), predmetnosti in pojavnosti (npr. kamen spotike, lakota je najboljši kuhar), času in prostoru (npr. na vrat na nos, hiti počasi), pa tudi o količini, meri in stopnji (npr. levji delež, $v$ tretje gre rado). Z upoštevanjem osnovnih kriterijev smo prišli do izbora sto frazemov in sto pregovorov, ki izkazujejo zadostno aktualnost, didaktično relevantnost ter jih lahko umestimo v različne tematske skupine.

\subsection{Priprava slovarskih opisov frazemov in pregovorov - FRIDA}

Za izbranih dvesto enot smo v nadaljevanju pripravili celostne slovarske opise in jih zbrali v zbirki, ki smo jo poimenovali FRIDA (Frazemi in pRegovorI na DlAni). Najprej smo v programskem vmesniku izdelali večnivojsko podatkovno shemo in vanjo začeli vnašati podatke. Na prvem nivoju smo opazovali oblikovne in tipološke lastnosti izbranih enot, na drugem nivoju pomensko-pragmatične lastnosti, na tretjem nivoju pa njihove slovnične lastnosti. Opisne formulacije smo vseskozi prilagajali primarnim uporabnikom e-okolja, torej učencem in dijakom, ter pri tem sledili nazornosti, jasnosti in razumljivosti. Četrti nivo je bil namenjen navajanju dodatnih zgledov rabe, ki bi bili uporabni pri pripravi vaj. Pri tem smo bili posebej pozorni na zglede z več frazeološkimi enotami, na pojasnjevanje izvora posameznih enot (npr. na mitološka pojasnila in etimološke razlage), na opažene dobesedne pomene pri enotah, ki omogočajo t. i. dvojno branje (Kržišnik, 2006, str. 260), na prisotnost uvajalnih sredstev ipd. Vseskozi smo pazili na zadostno navajanje besedilnega okolja, iz katerega je možno razpoznati pomen predstavljenih frazeoloških enot. Uporabniku se opisi prikazujejo v prilagojeni zaslonski sliki, pri čemer sledimo njegovemu interesu in omogočamo večnivojski prikaz z možnostjo selektivnega izbiranja podatkov v razponu med osnovnim in razširjenim oz. celostnim prikazom (prim. tudi Jesenšek in Ulčnik, 2014, str. 286). Za frazeme so tako sprva prikazani le izhodiščna enota, parafraza in zgled, šele v naslednji fazi pa pomenski opis, pragmatična pojasnila, morebitne so- in 
protipomenske enote ipd. Pri pregovorih izhodiščni enoti sledita pomenski opis in zgled, dodane pa so tudi opažene pragmatične značilnosti, sopomenske enote in variante. Izdelani slovarski opisi imajo dvojno funkcijo - služijo podrobnejšemu seznanjanju s konkretnimi frazemi in pregovori, preverjanju njihovega pomena in rabe, obenem pa smo zbrane podatke skušali v čim večji meri izkoristiti tudi pri zasnovi in pripravi vaj.

\subsection{Priprava vaj za frazeološke vsebine}

Pripravljeni slovarski opisi so bili torej z množico podatkov izhodišče za zasnovo vaj s področja frazeologije. V osnovi smo želeli ponuditi vaje različnih zahtevnostnih ravni (osnovna, srednja, zahtevna) in obenem zajeti različne tipe vaj (izbiranje, razvrščanje, dopolnjevanje ...). Na podlagi spoznanj teoretične frazeologije in skladno z izsledki frazeodidaktike (Kržišnik, 2015; Kacjan in Jesenšek, 2010) smo vaje kategorizirali v tri vsebinske podsklope: (1) podoba, (2) pomen in (3) raba frazemov ter pregovorov. V prvem podsklopu se pojavljajo vaje osnovne in srednje zahtevnostne ravni. Njihov namen je doseči, da uporabniki e-okolja frazeme in pregovore prepoznajo v besedilu, da se zavedajo njihove oblikovne oz. sestavinske podobe (večbesednost, ustaljenost) in da znajo ločevati med frazemi ter pregovori. Te vaje so konkretno vezane na prepoznavanje frazemov in pregovorov v besedilu, označevanje njihovih sestavin, dopolnjevanje manjkajočih sestavin ipd. Pri posameznih vajah so dodani tudi elementi igrifikacije, npr. spomin - povezovanje frazema s sliko, povezovanje prvega in drugega dela pregovora; sestavljanka - sestavljanje frazemov oz. pregovorov iz danih sestavin. V drugem podsklopu so vaje vseh treh zahtevnostnih ravni, pri čemer preverjamo razumevanje pomena frazeoloških enot, (pre)poznavanje medfrazemskih razmerij (so- in protipomenskost), zmožnost pomenskega pojasnjevanja enot ter sposobnost njihovega nadomeščanja s slogovno nezaznamovanimi besedami. Uporabnik mora npr. ustrezno povezati enoto s pomenom, prepoznati zgled brez frazema (v njem je besedna zveza uporabljena v dobesednem pomenu, npr. pustiti na cedilu: Jajčevca narežemo na debelejša kolesca, nasolimo in pustimo na cedilu 15 minut), povezati so- in protipomenske enote, na podlagi pomena enote razvrstiti v ustrezne tematske skupine, namesto frazemov uporabiti nevtralne besede, razložiti pomen frazemov in pregovorov, uporabljenih $\mathrm{v}$ zgledu. V tretjem podsklopu so vaje srednje in zahtevne ravni. Osredinjamo 
se na ustrezno frazeološko rabo ter sposobnost nadomeščanja nezaznamovanega izražanja s frazeološkim. Pri pregovorih smo posebej pozorni tudi na uveljavljeno rabo s t. i. uvajalnimi sredstvi. Uporabnik mora npr. izbrati ustrezni frazem in z njim dopolniti zgled, dokončati poved z ustreznim frazemom, za označeni del povedi uporabiti ustrezni frazem, izbrati zgled, ki vsebuje uvajalno sredstvo (npr. znana modrost, ljudski pregovor, kot pravijo). Vajam smo dodali še nekaj ustvarjalnih nalog oz. izzivov. Pri teh se uporabnik npr. preizkusi kot slovaropisec (s seznama izbere enoto in jo po navodilih in skladno z danim zgledom slovarsko opiše), izpolni atlas pregovorov, tvori kratko besedilo (npr. horoskop, šalo) in v njem uporabi frazeme in/ali pregovore, izraža svoje mnenje o resničnosti in aktualnosti izbranega pregovora (npr. obleka naredi človeka).

\section{KOMPETENCE RAZUMEVANJA IN TVORJENJA BESEDIL}

Jezik kot pomen, izražen z zvokom, ni le sporazumevalno sredstvo, ampak je neposredno povezan z razmišljanjem. Kot tak je v različnem obsegu sestavina skoraj vsake človekove aktivnosti v skupnosti ali različnih skupinah. Zato naj bi posameznik za delovanje in sodelovanje v skupnosti ali tudi za samorealizacijo razvijal sporazumevalno jezikovno zmožnost tvorjenja in razumevanja večpredstavnostnih klasičnih ali elektronskih pisanih in govorjenih besedil. To je tudi temeljni cilj področja o besedilih znotraj projekta Slovenščina na dlani. S tem ciljem so povezani cilji razvijanja kritičnega branja, pridobivanja znanja o jezikovni rabi in načrtno ter usmerjeno učenje o prvinah določenega besedila kot predstavnika določene besedilne skupine. Navedeni cilji so nujni, da lahko govorimo o razvijanju sporazumevalne jezikovne zmožnosti, saj le primerno visoka žanrska pismenost »uporabnikom jezika zagotavlja prepoznavanje in učinkovito rabo žanrov« (Nidorfer Šiškovič, 2013, str. 273). Razumevanje besedila pa ni le proces prepoznavanja prvin nejezikovnega in jezikovnega konteksta s posameznikovega stališča, zato je pri nalogah, zlasti vezanih na vsebino in smisel besedilnega sporočila, bila potrebna precejšnja mera natančnega branja ter posledično oblikovanja enoumno zastavljenih in smiselnih nalog. V ta namen smo za področje besedil oblikovali zbirko BERTA in vmesnik Berta. 


\subsection{Priprava gradiva za vaje in naloge s področja besedil ${ }^{18}$}

Za pripravo gradiva, tj. oblikovanje zbirke BERTA, smo najprej pregledali učne načrte in učbeniško gradivo od šestega razreda osnovne šole dalje, da bi lahko oblikovali nabor besedilnih skupin, učnih ciljev in uporabljenih strokovnih terminov, ki naj bi jih učeči se poznali oz. dosegli na določeni stopnji.

Pri oblikovanju nabora besedilnih skupin in tudi pri drugih teoretičnih odločitvah se je bilo treba opredeliti do različnih terminov za poimenovanje in pojmovanje, npr. množice besedil. V pregledanem osnovno- in srednješolskem gradivu se za poimenovanje množice besedil uporablja termin besedilna vrsta. Besedilne vrste, kot jih razumemo tukaj, se z večrazsežnostnega vidika besedila oblikujejo glede na značilne skupne kontekstualne in strukturne prvine, ki so medsebojno povezane in soodvisne. Besedilne vrste oblikujejo okvir za prototipične prvine konkretnega besedila. Te prvine so osnovane na dogovorih jezikovnih uporabnikov o jezikovnih/govornih vzorcih. Hkrati besedilne vrste izkazujejo prototipične funkcijske, medijsko-položajne in tematske prvine ter skladno s temi prvinami značilno strukturo besedila (Gansel in Jürgens, 2007). Besedilne vrste so produkti konvencionalnih jezikovnih dejanj znotraj posameznega komunikacijskega področja (Heinemann, 2000). Tovrstna opredelitev besedilne vrste je pokazala, da v učnih procesih učeči se pravzaprav ne spoznavajo prvin besedilnih vrst ali le redko, temveč v veliki večini primerov spoznavajo značilnosti besedilnih tipov, npr. prošnja, zahvala, voščilo. Besedilni tip je namreč skupina besedil s skupnimi ali podobnimi jezikovnimi značilnostmi in je vir za oblikovanje besedilnih vrst. Da bi se izognili nejasnostim in zmedi, smo vpeljati termin, ki vključuje tako besedilne tipe kot vrste, to je besedilna skupina.

Pri izbiranju besedilnih skupin smo dajali prednost tistim, ki nastajajo v za večino govorcev slovenščine pomembnih ali priljubljenih, v vsakem primeru pa živih in aktualnih komunikacijskih položajih, zato smo se odločili za nabor 29 besedilnih skupin, med drugimi za pritožbo, novico, vremensko napoved,

18 Dogovor znotraj projektne skupine je, da termin vaja razumemo kot vadenje, urjenje znane učne snovi, torej ponavljanje in utrjevanje že znanega, medtem ko termin naloga razumemo kot aktivnost, ki zajema reševanje novih jezikovnih problemov in vključuje ustvarjalnost, več miselnega angažmaja učečih se, zato je razumljivo, da se na področju besedil uporabljata oba termina. 
telefonski pogovor, govorni nastop, prijavnico, življenjepis, opis postopka, poljudnoznanstveni prispevek. Poleg prototipskih predstavnikov besedilne skupine smo želeli zbrati tudi nekaj neprototipskih, inovativnih, saj je tudi za vsakodnevne komunikacijske položaje značilna ustvarjalnost.

Sledilo je izbiranje tematskih sklopov in znotraj njih tematik, ki naj bi jih vsebovale izbrane besedilne skupine. Pri izbiranju tematskih sklopov in tematik smo izhajali iz sporazumevalnih tem za poučevanje slovenščine ali katerega koli drugega jezika kot drugega jezika (SEJO, 2011), npr. narava, zdravje, odnosi, poklic; SEJO je namreč »dokument, ki je pomemben za jezikovno poučevanje nasploh, ne samo poučevanje tujih jezikov« (SEJO, 2011, str. 5).

Na osnovi izbranih tematskih sklopov, besedilnih skupin in tematik smo oblikovali scenarij njihovega povezovanja in primernosti obravnave po razredih oz. letnikih. Del tega scenarija je slogan kot orientacijska točka, komu so besedila določene besedilne skupine, tematskega sklopa in tematike namenjena. Preglednica 1 prikazuje slogan Lačen kot Lakotnik.

Preglednica 1: Izsek preglednice P-BERTA

\begin{tabular}{|c|c|c|c|c|}
\hline $\begin{array}{l}\text { Tematski } \\
\text { sklop }\end{array}$ & Slogan & Tematika & $\begin{array}{l}\text { Besedilna } \\
\text { skupina }\end{array}$ & Naslov besedila \\
\hline \multirow[t]{10}{*}{ Zdravje } & \multirow{10}{*}{$\begin{array}{l}\text { Lačen kot } \\
\text { Lakotnik }\end{array}$} & \multirow[b]{2}{*}{ čokolada } & novica & Temna čokolada je lahko tudi zdrava \\
\hline & & & $\begin{array}{l}\text { kuharska } \\
\text { oddaja }\end{array}$ & Prigrizek v somraku \\
\hline & & \multirow{2}{*}{ češnje } & novica & $\begin{array}{l}\text { Japonska v pričakovanju čarobnega } \\
\text { cvetenja češenj }\end{array}$ \\
\hline & & & $\begin{array}{l}\text { kuharski } \\
\text { recept }\end{array}$ & Češnjev sladoled \\
\hline & & \multirow{2}{*}{ agrumi } & novica & $\begin{array}{l}\text { Veste, zakaj se pomaranče vedno } \\
\text { prodajajo v rdečih mrežastih vrečkah? }\end{array}$ \\
\hline & & & $\begin{array}{l}\text { kuharski } \\
\text { recept }\end{array}$ & Solata $\mathrm{z}$ agrumi \\
\hline & & \multirow{2}{*}{ paradižnik } & novica & $\begin{array}{l}\text { Z razkritim genskim zapisom do } \\
\text { okusnejšega paradižnika }\end{array}$ \\
\hline & & & $\begin{array}{l}\text { kuharski } \\
\text { recept }\end{array}$ & Posušeni paradižniki \\
\hline & & \multirow{2}{*}{ sivka } & novica & $\begin{array}{l}\text { Sivka iz Brij se je preselila na slikarska } \\
\text { platna }\end{array}$ \\
\hline & & & $\begin{array}{l}\text { kuharski } \\
\text { recept }\end{array}$ & Sivkina limonada \\
\hline
\end{tabular}


Sledila sta zbiranje konkretnih posameznih besedil in pridobivanje soglasij za njihovo uporabo. Tako je nastala zbirka BERTA (BEsedil pRakTičnega sporazumevanjA), ki ima dva podkorpusa, in sicer govornega (G-BERTA, 59 besedil) in pisnega (P-BERTA, 216 besedil), skupno 275 besedil. Zajema besedila, ki so vsebinsko in po načinu obravnave vsebine blizu šolajoči se mladini od 11. do 19. leta starosti. Za lažjo orientacijo uporabnikov (učiteljev in učečih se)

Preglednica 2: Izsek preglednice Metakazalo vaj

\begin{tabular}{|c|c|c|}
\hline \multirow{26}{*}{ Besedilo } & \multirow{6}{*}{ Šolske besedilne skupine 1} & Opis življenja osebe \\
\hline & & Pripoved o življenju osebe \\
\hline & & Življenjepis \\
\hline & & Prijava \\
\hline & & Prošnja \\
\hline & & Pritožba \\
\hline & \multirow{6}{*}{ Šolske besedilne skupine 2} & Opis postopka \\
\hline & & Esej \\
\hline & & Prijavnica \\
\hline & & Vabilo \\
\hline & & Govorni nastop \\
\hline & & $\begin{array}{l}\text { Poljudnoznanstveni } \\
\text { prispevek }\end{array}$ \\
\hline & \multirow{7}{*}{ Besedilne skupine od tu in tam } & Telefonski pogovor \\
\hline & & Razgovor \\
\hline & & Anekdota \\
\hline & & Kuharska oddaja \\
\hline & & Filmski napovednik \\
\hline & & Ocena \\
\hline & & Prepričevalni pogovor \\
\hline & \multirow{7}{*}{ Besedilne skupine $v$ medijih } & Intervju \\
\hline & & Mali oglas \\
\hline & & Oglas \\
\hline & & Vremenska napoved \\
\hline & & Horoskop \\
\hline & & Novica \\
\hline & & Šala \\
\hline
\end{tabular}


smo scenarij s slogani nadomestili z razdelitvijo vseh besedilnih skupin na štiri množice (Preglednica 2).

Zbirka BERTA je bila dokončno oblikovana, ko smo običajnemu korpusnemu označevanju dodali še oznake, pomembne za priklic besedila kot primernega za določeno stopnjo in doseganje želenega učno-vzgojnega cilja. Zajeta besedila so zato opremljena s podatki o tvorcu, naslovniku, mestu in času objave/ nastanka besedila, javni dostopnosti besedila, jezikovni zvrsti, številu udeležencev, sporočevalnem namenu, funkciji besedila, slogovnem postopku, tematskem sklopu, tematiki, temi, prenosniku in zahtevnosti besedila (osnovna, srednja, zahtevna). Uporabnikom bodo prikazana večpredstavnostno in $\mathrm{v}$ celoti (npr. pdf-posnetek besedila, video/avdio posnetek), tako da bodo vidni tudi neverbalni elementi. Za doseganje nekaterih učnih ciljev, npr. za določitev ubeseditvenega načina, smo daljša besedila, npr. poljudnoznanstvene prispevke, členili na odlomke.

\subsection{Priprava vaj in nalog za področje besedil - vmesnik BERTA}

Besedila ni mogoče obravnavati na enak način kot slovnična ali pravopisna pravila, saj so besedila aktualizacija in uresničitev teh pravil. Zgodi se, da ni mogoče le eno in zato pravilno interpretiranje besedila. Zdi se, da je težnja po le eni pravilni interpretaciji prisotna v izobraževalnem procesu, ko sicer zanimivemu besedilu sledijo tri ali štiri naloge, ki od učečega se zahtevajo poznavanje kraja in časa nastanka besedila, udeležencev, njihovega družbenega razmerja. Tem nalogam sledijo še vprašanja o temi in sporočevalnem namenu ter določitev ubeseditvenega načina, ki temelji bolj na občutku kot na dejanskih značilnostih besedila. Ostale naloge se nanašajo na slovnično in/ali leksikalno raven. Temu načinu dela smo se želeli izogniti. Oblikovali smo vmesnik BERTA, v katerega k posameznemu besedilu vnašamo trditve, vprašanja in druge podatke, potrebne za programiranje in dokončno oblikovanje vaj in nalog, ki se nanašajo izključno na besedilne značilnosti posameznega besedila, njegove morebitne druge jezikovne značilnosti pa so izpostavljene le, če so povezane z značilnostmi besedilne skupine.

Tako v vmesnik BERTA k posameznemu besedilu v štiri sklope vnašamo ločene trditve, vprašanja in odgovore ter napačne alternative. Prvi sklop nalog je vezan na nejezikovne prvine konteksta, ki so bile skupaj s tematskim sklopom, 
besedilno skupino, temo in jezikovno zvrstjo že popisane pri vnašanju besedila v zbirko BERTA. Drugi sklop vaj in nalog je vezan zlasti na jezikovne prvine besedila kot predstavnika določene besedilne skupine. Zanemarjen ni niti večpredstavnostni vidik, saj ta lahko bistveno prispeva $\mathrm{k}$ interpretaciji besedilnega sporočila, na kar opozarjata npr. S. Starc (2011, str. 434) in B. Vičar (2015, str. 802). Z nalogami je opozorjeno na morebitna odstopanja od pričakovanega, npr. vabilo na klekljarski krožek, ki je v obliki opisa postopka. Uporabnik bo prek nalog in vaj opazoval ter spoznaval značilno leksiko in oblikoslovne značilnosti posamezne besedilne skupine; za novico oz. vest je npr. značilna sintagma po poročanju $X$, za horoskop pa strokovni termini s področja astronomije in astrologije, npr. Sonce $v$ ozvezdju Raka (Krajnc Ivič, 2019). Za opis postopka je značilna raba sedanjiških prvoosebnih množinskih glagolskih oblik, pojavi pa se celo tretjeosebna edninska. Uporabnik bo tako spoznaval, da je uresničitev jezikovnih prvin posameznega besedila odvisna od komunikacijskega področja, znotraj katerega je besedilo nastalo, od teme in namena besedila ter dalje od ubeseditvenega načina oz. slogovnega postopka. $\mathrm{V}$ tretji sklop sodijo vaje in naloge, vezane na vsebino posameznega besedila, ki lahko dodatno utemeljijo določitev sporočevalnega namena ali slogovnega postopka konkretnega besedila. Četrti sklop predstavljajo naloge tvorjenja besedil, pri katerih želimo, da uporabnik povzame, obnovi izhodiščno besedilo ali tvori besedilo iste ali druge besedilne skupine. To pomeni, da praktično prikaže razumevanje pridobljenega znanja. Tovrstne naloge od uporabnika zahtevajo še dvoje, in sicer kritičen razmislek o prebranem/slišanem/ ogledanem in sodelovanje z vrstniki. Preglednica 3 prikazuje primere trditev, alternativ in vprašanj za vsak sklop nalog in vaj. 
Preglednica 3: Primeri trditev in vprašanj v vmesniku BERTA $k$ besedilu o terapiji s konji

\begin{tabular}{|c|c|c|}
\hline TIP & $\begin{array}{l}\text { TRDITEV/VPRAŠANJE IN S } \\
\text { KREPKIM TISKOM OZNAČENA } \\
\text { PRAVILNA REŠITEV/ODGOVOR }\end{array}$ & ALTERNATIVE ${ }^{19}$ \\
\hline \multicolumn{3}{|c|}{ Prvi sklop vaj in nalog } \\
\hline \multicolumn{3}{|c|}{ PRAVILNE TRDITVE } \\
\hline Tvorec & $\begin{array}{l}\text { Tvorec izhodiščnega besedila } \\
\text { je Kristijan Skok. }\end{array}$ & $\begin{array}{l}\text { - Jen Mundy } \\
\text { - Lis Hartel } \\
\text { - M. Demšar }\end{array}$ \\
\hline \multicolumn{3}{|c|}{ Drugi sklop vaj in nalog } \\
\hline \multicolumn{3}{|c|}{ PRAVILNE TRDITVE } \\
\hline $\begin{array}{l}\text { Sporočevalni } \\
\text { namen }\end{array}$ & $\begin{array}{l}\text { Namen izhodiščnega besedila } \\
\text { je naslovnike informirati o konjih } \\
\text { in razlogih za izbiro konj v terapevtske } \\
\text { namene. }\end{array}$ & $\begin{array}{l}\text { - bralce prepričati } \\
\text { - izraziti brezbrižnost } \\
\text { - najti ugotovitve }\end{array}$ \\
\hline \multicolumn{3}{|l|}{ VPRAŠANJA } \\
\hline Leksika & $\begin{array}{l}\text { Katero izrazje je značilno za izhodiščno } \\
\text { besedilo kot poljudnoznanstveni } \\
\text { prispevek? Poljudnoznanstveno } \\
\text { besedje, splošno znani strokovni } \\
\text { termini in iz latinščine prevzete } \\
\text { besede. }\end{array}$ & 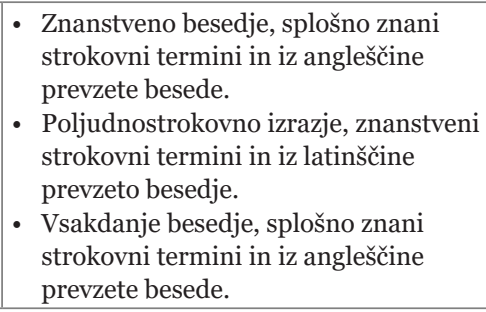 \\
\hline \multicolumn{3}{|c|}{ Tretji sklop vaj in nalog } \\
\hline \multicolumn{3}{|c|}{ PRAVILNE TRDITVE } \\
\hline Vsebina & $\begin{array}{l}\text { Starost konja je mogoče določiti } \\
\text { po njegovih zobeh. }\end{array}$ & $\begin{array}{ll}\text { - } & \text { njegovi čeljusti } \\
\text { - } & \text { njegovi grivi } \\
\text { - } & \text { njegovih očeh } \\
\end{array}$ \\
\hline \multicolumn{3}{|c|}{ NAPAČNE TRDITVE } \\
\hline Vsebina & $\begin{array}{l}\text { Konji se hranijo predvsem s } \\
\text { koncentrirano hrano, kot sta npr. trava } \\
\text { in seno. }\end{array}$ & \\
\hline \multicolumn{3}{|l|}{ VPRAŠANJA } \\
\hline & $\begin{array}{l}\text { Kako konji glede na izhodiščno } \\
\text { besedilo izražajo svoje razpoloženje? } \mathbf{Z} \\
\text { obračanjem uhljev, mahanjem } \mathbf{z} \\
\text { repom in s šobljenjem. }\end{array}$ & $\begin{array}{l}\text { - } \mathrm{z} \text { obračanjem glave, mahanjem z } \\
\text { repom in s poskakovanjem } \\
\text { - } \text { z obračanjem uhljev, mahanjem z } \\
\text { repom in s poskakovanjem } \\
\text { - } \text { z obračanjem glave, mahanjem z } \\
\text { repom in z rezgetanjem }\end{array}$ \\
\hline \multicolumn{3}{|c|}{ KLJUČNE BESEDE } \\
\hline \multicolumn{3}{|c|}{ terapija | konj | proces | jahanje | učinki | človek | odnos } \\
\hline \multicolumn{3}{|c|}{ Četrti sklop vaj in nalog } \\
\hline \multicolumn{3}{|c|}{ BESEDILNE NALOGE } \\
\hline $\mathrm{TB}+\mathrm{T}$ & Opiši, kako poteka terapija s konjem. & \\
\hline
\end{tabular}

19 Navedene so napačne možnosti. 
Vsako pregledano besedilo ima povprečno od 15 do 25 trditev in okoli 4 vprašanja za vse štiri sklope. Število trditev in vprašanj je odvisno od dolžine besedila.

\section{PROGRAMIRANJE IN VREDNOTENJE VAJ TER IZDELAVA RAZLAG}

V fazi programiranja e-okolja smo morali razviti postopek, ki bo uporabnikom omogočal reševanje vseh zamišljenih vaj. Ta postopek sestoji iz več korakov. Najprej se morajo generirati primeri, ki so na voljo za reševanje. Osrednji del celotnega postopka predstavlja prikaz vaje in njeno reševanje. Pomembno vlogo v e-okolju ima tudi algoritem, ki skrbi za določanje zaporedja reševanja vaj. $\mathrm{Na}$ koncu je treba še ovrednotiti uporabnikove poskuse reševanja. Sočasno s programiranjem smo izdelali še bazo razlag, ki je uporabnikom v pomoč pri reševanju.

\subsection{Generiranje primerov vaj}

Pravila za generiranje primerov smo določili že v fazi definiranja vaj v posameznih vsebinskih področjih. Glavni izziv je predstavljalo generiranje primerov za vaje, ki uporabniku ponujajo napačne odgovore. To so na primer naloge tipa 'Izberi pravilen odgovor' ali 'Popravi odgovor'. Pomembno je namreč, da napačni primeri niso preveč nesmiselni, kar bi uporabniku olajšalo reševanje. $\mathrm{S}$ tem bi se zmanjšal miselni napor uporabnika pri reševanju teh nalog, kar bi privedlo do upočasnjenega napredka v njegovem znanju.

Na področjih pravopisa in slovnice smo s pomočjo gradnikov in vnaprej določenih pravil uspeli vzpostaviti popolnoma avtomatiziran proces, ki iz korpusa besedil tvori primere za posamezno vajo. S pravili smo uspeli avtomatsko tvoriti tudi pravopisno oz. slovnično napačne povedi za vaje, kjer je bilo to potrebno. Proces je podrobneje opisan v poglavju 3.5.

Na področju frazemov in pregovorov smo primere generirali na podlagi informacij v slovarskih opisih. Pri tem smo spoznali, da računalnik ni zmožen tvoriti ustreznih alternativnih primerov za vaje, kjer so bili ti potrebni. ${ }^{20} \mathrm{Na}$

20 Npr. pri vaji, kjer je izločena ena sestavina frazema in mora uporabnik med štirimi ponujenimi odgovori izbrati ustreznega (primer: narediti iz muhe ... - ob ustrezni sestavini slona z avtomatskim iskanjem težko dobimo relevantne alternativne odgovore, ki zagotavljajo tudi ustrezno zahtevnost naloge). 
tem mestu je namreč treba tvoriti smiselne alternative, kar je prezahtevno za računalniške algoritme. Da smo rešili težavo, smo zapise v slovarskih opisih dopolnili še z dodatnimi informacijami, ki jih računalnik uporabi pri generiranju takih primerov vaj.

Na področju besedil se primeri nalog pogosto nanašajo na pomen obravnavanega besedila. Teh primerov nismo mogli tvoriti povsem avtomatsko, zato smo pri vsakem besedilu zapisali nekaj trditev, vprašanj in pravilnih odgovorov, na podlagi katerih lahko računalnik tvori naloge tipa 'Odgovori na vprašanje', 'Izberi pravilen odgovor' ali celo uporabi več vprašanj in tvori nalogo 'Poveži vprašanja s pripadajočimi odgovori'. S takim polavtomatskim pristopom smo prihranili čas, ki bi ga sicer potrebovali za ročno tvorjenje nalog, in hkrati povečali nabor vaj, ki se nanašajo na pomen zapisanega ali govorjenega besedila. Pri določenih trditvah in vprašanjih smo zapisali tudi alternativne napačne odgovore, ki se uporabljajo za tvorbo nalog, pri katerih mora uporabnik prepoznati oz. popraviti napačen odgovor.

\subsection{Prikaz in reševanje vaj}

Osrednji del programiranja vaj predstavljata prikaz vaje in njeno reševanje. V tej fazi smo poskrbeli, da e-okolje ponuja interaktiven način reševanja, ki uporabnika spodbuja k uporabi. Načrtovani uporabniški vmesniki za reševanje so prilagojeni različnim napravam in potrebam uporabnikov.

Programska predstavitev vaje je uporabniku prikazana v obliki spletnega uporabniškega vmesnika, katerega videz močno variira glede na tip naloge. Za ustrezen prikaz posameznega primera se uporablja podatkovni zapis primera v obliki JSON, v katerem je primer razdelan tako, da določa, kateri so tisti elementi, kjer bo mogoča interakcija. Iz slednjega se nato generira uporabniški vmesnik, kjer so v besedilo dodani vnosni elementi, določene elemente, kot so vejice ali besede, pa je mogoče izbrati ali jih premikati po besedilu. Prav tako ima uporabnik pri določenih tipih nalog na izbiro različne možnosti, sam pa se mora odločati o njihovi pravilnosti. Pri posebnih uporabniških vmesnikih, kot so za rešeta ali sestavljanke, so v zapisih primera vključeni seznami alternativnih besed ali delov povedi, tako da omogočajo generiranje vmesnika. V vseh vmesnikih je treba ustrezno hraniti uporabnikovo interakcijo, saj se poleg vnosa, kot je besedilo ali izbira, beležita tudi uporabnikovo napačno 
ravnanje ter čas, ki ga potrebuje za posamezno akcijo. Akcije se sproti beležijo in posredujejo v zaledje učnega sistema, kjer so ovrednotene, saj se na njihovi podlagi po logični shemi prožijo različne druge akcije. Logična shema se prav tako obnaša dinamično, saj so podatki zapisani v podatkih primera in so odvisni tudi od vrste opravila, ki ga uporabnik opravlja, prav tako pa tudi od uporabniškega konteksta. Vse navedeno vpliva na odziv uporabniškega vmesnika, ki lahko nato ponudi pomoč pri neuspešnem reševanju, ovrednoti posamezno reševanje in na koncu vpliva tudi na izbor naslednjega primera za reševanje. Omenjeni proces je zasnovan tako, da ga lahko uporabimo za prikazovanje in reševanje vaj na vseh področjih v e-okolju. Manjša posebnost so le vaje s področja besedil, kjer je uporabniku ob reševanju vedno na voljo še vpogled v izhodiščno besedilo.

Zaporedje, po katerem se prikazujejo primeri za reševanje, je odvisno od mnogih dejavnikov. Vzpostavili smo sistem, ki na podlagi statističnih modelov in vnaprej določenih pravil adaptivno izbira vaje in primere, ki jih rešuje uporabnik. Ločimo več načinov delovanja, ki so odvisni od uporabniškega vnosa. Vaje in naloge lahko uporabnik rešuje samostojno; v tem primeru si sam izbere nabor poglavij, ki jih želi vaditi. Druga možnost je, da mu nabor za reševanje dodeli učitelj; pri tem učitelj izbere poglavja in tudi posamezne vaje ter naloge, ki jih bo uporabnik reševal. Tretji način pa predstavljajo predlogi e-okolja, ki na podlagi zgodovine reševanja uporabniku predlaga primerne vaje in naloge za nadaljnje utrjevanje znanja; znotraj izbranega načina delovanja zaporedje prikaza vaj, nalog in primerov določa e-okolje. Pri tem upoštevamo težavnostno stopnjo, uporabnikovo starost oz. razred, ki ga obiskuje, in tudi njegovo uspešnost pri preteklih poskusih reševanja. Določena težavnostna stopnja vaje, naloge oz. primera se med uporabo e-okolja prilagaja tudi glede na uspešnost, ki so jo imeli uporabniki pri reševanju. Na ta način lahko avtomatično odpravimo morebitne človeške napake pri določanju težavnostne stopnje.

\subsection{Vrednotenje}

Ko uporabnik rešuje vaje, se izvaja vrednotenje. Najprej se ovrednoti pravilnost rešitve posameznega primera. Nadalje se vrednoti uporabnikova uspešnost pri reševanju posamezne zadolžitve, npr. domače naloge. Na koncu pa e-okolje vrednoti še uporabnikovo skupno znanje znotraj določenega poglavja. 
Vrednotenje uporabnikovih rešitev poleg končnega odgovora upošteva še vmesne korake, porabljen čas in napačne poskuse. Vrednotenje lahko poteka na tri načine. Prvi način je samodejno vrednotenje, kjer vnaprej poznamo pravilno rešitev in jo lahko v času reševanja ovrednotimo. Tak način uporabniku ob reševanju daje neposredno povratno informacijo. Drugi način je samovrednotenje, ki izhaja iz principa navajanja možnih pravilnih odgovorov, ki se po reševanju prikažejo uporabniku, nato pa ta na podlagi ponujenih možnosti ovrednoti svoj odgovor in s tem presodi lastno uspešnost (Holcar Brunauer idr., 2019, str. 3). Tega smo uporabili pri nalogah, ki imajo različne možne rešitve (npr. razlaga pomena frazema ali pregovora) oz. so vezane na uporabnikovo ustvarjalnost (raba frazemov in pregovorov). Gre za naloge, ki izhajajo iz problemskega pristopa in pri katerih je vključeno doseganje višjih taksonomskih ravni (analiza, sinteza, vrednotenje). Pri tretjem načinu rešitev ovrednoti drug uporabnik, običajno v vlogi učitelja ali tutorja. Po tem načinu lahko poseže uporabnik, ki ni prepričan v svoje sposobnosti, da bi izvedel samovrednotenje, lahko pa ga določi tudi učitelj ob dodelitvi nalog, ki jih ni mogoče samodejno vrednotiti. Inovativne možnosti vrednotenja od uporabnikov zahtevajo kritično presojo in spodbujajo prevzemanje odgovornosti za lastno učenje oz. ustvarjajo možnosti za nudenje medvrstniške povratne informacije, s tem pa si učeči se pridobivajo pomembne učne izkušnje.

Vrednotenje uporabnikove uspešnosti pri reševanju posamezne zadolžitve temelji na seštevanju ovrednotenih posameznih primerov, ki jih je uporabnik rešil v sklopu zadolžitve. Pri vrednotenju uporabnikovega skupnega znanja znotraj določenega poglavja v e-okolju se upoštevajo vsi primeri iz določene tematike, ki jih je uporabnik rešil. Rezultat vrednotenja se uporabniku prikaže v obliki različno obarvanih medalj in dosežkov, ki ga dodatno motivirajo k reševanju. Rezultat se upošteva pri določitvi težavnostne stopnje primerov vaj in nalog, ki se uporabniku prikazujejo med reševanjem. Vrednotenje ni izvedeno enostavno linearno, ampak je prožno in upošteva različno stopnjo predznanja uporabnikov. Cilj je namreč, da lahko uporabnik z več znanja pri določenem poglavju hitreje napreduje in ga zaključi z manj vajami oz. začne hitreje dobivati zahtevnejše vaje iz tega poglavja. 


\subsection{Razlage k vsebinam vaj}

Že Higgins in Johns (1984) izpostavljata, da učeči se želijo razlage k vajam, ki jim povedo, zakaj je nekaj pravilno ali napačno, in to ne samo takrat, ko ne poznajo prave rešitve, ampak tudi v primerih, ko vajo rešijo pravilno. Vsebinska področja vaj v učnem e-okolju Slovenščina na dlani so zato opremljena z razlagami o jezikovnih pravilih in vzorcih, na podlagi katerih so utemeljene pravilne rešitve. Učeči se lahko s preprostim klikom na ikono z vprašajem, ki je ves čas prisotna v zgornjem desnem kotu e-okolja, izve točno tisto razlago ob vaji, ki jo v nekem trenutku rešuje. Razlaga je najprej na voljo v krajši obliki in se prikaže v desnem delu okna ob primeru, ki ga uporabnik rešuje, dodana pa je povezava na daljšo razlago s primeri in ponazoritvami. Od slednje vodijo povezave tudi k sorodnim temam ali k izbranim relevantnim razlagam drugod na spletu. Slika 1 prikazuje primer kratke razlage za preverjanje začetnice pri zapisu zemljepisnih imen.

\section{Zemljepisna imena}

Zemljepisna imena poimenujejo kraje, ulice, mesta, naselja, države, jezera, morja, puščave, gore, otoke in druge zemljepisne danosti. Če o njih govorimo na splošno in nimamo v mislih posameznega mesta, države ali druge zemljepisne danosti, so to občna zemljepisna imena, ki jih pišemo z malo začetnico: mesto, vas, reka, morje, ledenik, slap in podobno. Kadar poimenujejo posamezno zemljepisno področje (ime kraja, ulice, države, jezera, morja, puščave, gore in podobno), so to lastna zemljepisna imena, ki jih pišemo z veliko začetnico: Piran, Slovenija, Cvetlična ulica, Bohinjsko jezero, Severno morje, Sahara, Raduha.

Slika 1: Kratka razlaga za preverjanje zapisa zemljepisnih imen.

Tehnično so razlage izvedene v obliki baze s približno 60 razlagami za pravopisne teme, približno 60 razlagami za slovnične teme, 39 razlagami za frazeme in pregovore ter 66 razlagami za besedila. Vsaka razlaga ima identifikatorje, ki določajo, pri katerih vajah naj se prikazuje. Razlage so sistematično urejene in dostopne tudi pod posebnim zavihkom Znanje, do katerega ima uporabnik dostop z osnovne strani.

\section{SKLEP}

V projektu Slovenščina na dlani s pomočjo jezikovnih virov in avtomatiziranih postopkov izdelujemo interaktivno učno e-okolje za podporo učenju slovenščine v osnovnih šolah od 6. razreda naprej in v srednjih šolah. Za potrebe tega e-okolja smo razvili manjši korpus besedil, primernih za mladino 
(MAKS), večmodalno zbirko besedil praktičnega sporazumevanja (BERTA), slovarske opise frazemov in pregovorov (FRIDA) in bazo razlag (Znanje). Izdelani viri bodo na voljo tudi kot jezikovni vir pod licencami CC BY, razen v primerih, kjer to ni mogoče zaradi omejitev pri izvornih avtorskih pravicah besedil oz. vsebin. Dostopni so oz. bodo prek repozitorija CLARIN.SI oz. prek Clarinovih konkordančnikov (https://www.clarin.si/noske/).

Skupno je pripravljenih več kot 1000 različnih vaj in nalog s področja pravopisa, slovnice, frazeologije in besedil ter razlage za skupno več kot 200 različnih z vajami povezanih tematik. Za vsako vajo je na voljo večje število različnih primerov, pri pravopisu in slovnici tudi do 500 za eno vajo. S tem odgovarjamo na izzive, kako odpraviti napake knjižne norme, ki vztrajajo v pisnih izdelkih učencev, kako izboljšati njihovo frazeološko kompetenco in sporazumevalno jezikovno zmožnost. Ključna prednost novega e-okolja pred ostalimi e-priročniki za pouk slovenščine z vidika učitelja (in učenca) je, da se e-okolje Slovenščina na dlani samodejno prilagaja potrebam učečega se in tako olajša delo učitelja pri formativnem spremljanju napredka posameznikov.

V šolskem letu 2020/21 v projektu Slovenščina na dlani nadaljujemo z zadnjo fazo izgradnje vaj, tj. s priklicem vaj iz zalednih baz v spletni vmesnik e-okolja, dodajanjem besedilnih nalog in pisanjem razlag, izdelavo različnih funkcionalnosti, kot so prikazovanje doseženih rezultatov, prikazovanje razlag ob vajah ipd., ter začenjamo testiranje e-okolja in analizo vedenja uporabnikov. S šolskim letom 2021/22 bo e-okolje dostopno zainteresirani javnosti na spletni povezavi https://slo-na-dlani.si/.

Avtomatizacija s podporo jezikovnih tehnologij in digitalno okolje imata nekaj prednosti, ki jih papirni medij ne omogoča: veliko količino primerov in vaj, prilagajanje zahtevnosti vaj znanju uporabnika, avtomatsko vrednotenje in usmerjanje med vajami, enostavno priklicljivo pomoč v obliki razlag, prilagojenih vsaki posamezni nalogi, podporo pri reševanju z namigi ali sprotno komunikacijo z drugimi uporabniki sistema ali sodelovanjem v skupinah. $\mathrm{Ob}$ raziskovanju možnosti za motivacijo in spodbujanje ustvarjalnosti pa smo ugotavljali tudi omejitve v primerjavi z osebnim stikom pri učenju. Ob tem da je učno e-okolje visoko avtomatizirano in v določeni meri individualizirano, namreč omogoča veliko manj ustvarjalnih in interaktivnih nalog. Avtorji 
e-okolja Slovenščina na dlani zato že od zasnove naprej sledimo načelu, da je digitalno učno e-okolje koristno dopolnilo in popestritev pouka, nikakor pa ne nadomestilo za tradicionalne oblike poučevanja.

\section{LITERAT URA}

Davies, G. (2016). CALL (Computer assisted language learning). Centre for Languages, Linguistics \& Area Studies. Pridobljeno s https://www.llas.ac.uk/ resources/gpg/61\#ref6

Dobrovoljc, K., Krek, S., \& Erjavec, T. (2015). Leksikon besednih oblik Sloleks in smernice njegovega razvoja. V V. Gorjanc, P. Gantar, I. Kosem in S. Krek (ur.), Slovar sodobne slovenščine: problemi in rešitve (str. 80-105). Ljubljana: Znanstvena založba Filozofske fakultete.

Gansel, C., \& Jürgens, F. (2007). Textlinguistik und Textgrammatik. Eine Einführung. 2. Auflage. Göttingen: Vandenhoeck \& Ruprecht.

Gomboc, M. (2019). Slovenščina. Po korakih do odličnega znanja. Ljubljana: Mladinska knjiga.

Grčar, M., Krek, S., \& Dobrovoljc, K. (2012). Obeliks: statistični oblikoskladenjski označevalnik in lematizator za slovenski jezik. V Zbornik Osme konference Jezikovne tehnologïje (str. 82-87). Pridobljeno s http://nl.ijs.si/ isjt12/JezikovneTehnologije2012.pdf

Heinemann, W. (2000). Textsorte - Textmuster - Texttyp. V K. Brinker, G. Antos, W. Heinemann in S. F. Sager (ur.), Text- und Gesprächslinguistik: ein internationales Handbuch zeitgenössischer Forschung. Handbücher zur Sprach- und Kommunikationswissenschaft, (zv. 16) (str. 507-523). Berlin, New York: Walter de Gruyter.

Higgins, J., \& Johns, T. (1984). Computers in Language Learning. London: Collins.

Holcar Brunauer, A., Bizjak, C., Cotič Pajntar, J. idr. (2019). Formativno spremljanje. Samovrednotenje, vrstniško vrednotenje. Ljubljana: Zavod Republike Slovenije za šolstvo.

Erjavec idr. (2010). The JOS Linguistically Tagged Corpus of Slovene. Proceedings of the Seventh Conference on International Language Resources and Evaluation (LREC'1O) (str. 1806-1809). Pridobljeno s http://www. lrec-conf.org/proceedings/lrec2010/index.html 
Jesenšek, V., \& Ulčnik, N. (2014). Spletni frazeološko-paremiološki portal: redakcijska vprašanja ob slovenskem jezikovnem gradivu. V V. Jesenšek in S. Babič (ur.), Več glav več ve: Frazeologija in paremiologija v slovarju in vsakdanji rabi (str. 276-292). Maribor: Oddelek za germanistiko, Filozofska Fakulteta Univerze v Mariboru, ZRC SAZU Ljubljana, Inštitut za slovensko narodopisje.

Jesenšek, V. (2018). Zakaj in čemu frazeologija pri pouku materinščine. V N. Ulčnik (ur.), Slovenščina na dlani 1 (str. 21-24). Maribor: Univerzitetna založba Univerze. Pridobljeno s http://press.um.si/index.php/ump/catalog/ book/341

Kacjan, B., \& Jesenšek, V. (2010). Pregovori pri učenju in poučevanju (tujega) jezika. V N. Holc (ur.), Posodobitve pouka v gimnazijski praksi (str. 59-67). Ljubljana: Zavod RS za šolstvo.

Kosem, I., Stritar, M., Može, S., Zwitter Vitez, A., Arhar Holdt, Š., \& Rozman, T. (2012). Analiza jezikovnih težav učencev: korpusni pristop. Ljubljana: Trojina, zavod za uporabno slovenistiko.

Krajnc Ivič, M. (2019). Frazeološke enote v horoskopih in malih oglasih - besedilnovrstni vidik. V Ž. Macan (ur.) Frazeologija, učenje i poučavanje (str. 171-184). Reka: Sveučilište u Rijeci Filozofski fakultet.

Krek, S., Dobrovoljc, K., Erjavec, T., Može, S., Ledinek, N., Holz, N., ..., Zajc, A. (2019). Training corpus ssj5ook 2.2, Slovenian language resource repository CLARIN.SI.

Križaj, M., \& Bešter Turk, M. (2018). Jezikovni pouk: Čemu, kaj in kako? Priročnik za učitelje in učiteljice slovenščine v osnovni šoli. Ljubljana: Rokus Klett.

Kržišnik, E. (2006). Izraba semantične potence frazemov. Slavistična revija, 56(1), 259-279.

Kržišnik, E. (2015). Frazeologija v šoli - drugič. Jezik in slovstvo, 6o(3-4), 131-142.

Ljubešić, N., \& Erjavec, T. (2016). Corpus vs. Lexicon Supervision in Morphosyntactic Tagging: the Case of Slovene. Language Resources and Evaluation Conference 2016.

Logar Berginc, N., Grčar, M., Brakus, M., Erjavec, T., Arhar Holdt, Š., \& Krek, S. (2012). Korpusi slovenskega jezika Gigafida, KRES, ccGigafida 
in ccKRES: gradnja, vsebina, uporaba. Ljubljana: Trojina, zavod za uporabno slovenistiko, Fakulteta za družbene vede. Pridobljeno s https://www.fdv.uni-lj.si/docs/default-source/zalozba/pages-from-logar-et-al---korpusi.pdf? sfvrsn $=2$

Meterc, M. (2017). Paremiološki optimum: Najbolj poznani in pogosti pregovori ter sorodne paremije $v$ slovenščini. Ljubljana: Založba ZRC, ZRC SAZU.

Meterc, M. (2019). Vpliv starosti na poznanost pregovorov, rekov in sorodnih paremij ter na paremiološko kompetenco slovenskih govorcev. V Ž. Macan (ur.), Frazeologija, učenje i poučavanje (str. 209-221). Rijeka.

Meterc, M. (2020). Slovar pregovorov in sorodnih paremioloških izrazov. Rastoči slovar. Pridobljeno s https://fran.si/

Nidorfer Šiškovič, M. (2013). Žanrskost funkcijskih besedilnih vrst. V A. Žele (ur.), Družbena funkcijskost jezika: vidiki, merila, opredelitve, Obdobja 32 (str. 269-275). Ljubljana: Znanstvena založba Filozofske fakultete.

Nivre, J., Marneffe, M., Ginter, F., Goldberg, Y., Hajič, J., Manning, C. D., ..., Zeman, D. (2016). Universal Dependencies v1: A Multilingual Treebank Collection. Proceedings of the Tenth International Conference on Language Resources and Evaluation (LREC'16). Portorož: European Language Resources Association.

Odpiranje izobraževanja: inovativno poučevanje in učenje za vse z novimi tehnologijami in prosto dostopnimi učnimi viri. Pridobljeno s https://eurlex.europa.eu/legal-content/SL/TXT/PDF/?uri=CELEX:52013DC06548from=HU

Rozman, T., Krapš Vodopivec, I., Stritar, M., \& Kosem, I. (2020). Empirični pogled na pouk slovenskega jezika. Ljubljana: Znanstvena založba FF UL. Pridobljeno s https://e-knjige.ff.uni-lj.si/znanstvena-zalozba/catalog/ view/227/327/5303-1

SEJO = Skupni evropski jezikovni okvir: učenje, poučevanje, ocenjevanje (2011). Irena Kovačič (pr.). El. knjiga. Ljubljana: Ministrstvo RS za šolstvo in šport, Urad za razvoj šolstva. Pridobljeno s https://centerslo.si/wp-content/ uploads/2015/10/SEJO-komplet-za-splet.pdf

Starc, S. (2011). Stik disciplin v besedilu iz besednih in slikovnih semiotskih virov. V S. Kranjc (ur.), Meddisciplinarnost $v$ slovenistiki, Obdobja 30 (str. 433-440). Ljubljana: Znanstvena založba Filozofske fakultete. 
Strateški okvir - Izobraževanje in usposabljanje 2020. Pridobljeno s http:// ec.europa.eu/education/policy/strategic-framework_sl

Ulčnik, N. (2019). Izbor frazemov za bazo FRIDA. V N. Ulčnik (ur.), Slovenščina na dlani 2 (str. 37-45). Ulčnik. Maribor: Univerzitetna založba Univerze. Pridobljeno s https://press.um.si/index.php/ump/catalog/book/447

Ulčnik, N., \& Meterc, M. (2019). Izbor pregovorov za bazo FRIDA. V N. Ulčnik (ur.), Slovenščina na dlani 2 (str. 47-55). Maribor: Univerzitetna založba Univerze. Pridobljeno s https://press.um.si/index.php/ump/catalog/book/447

Vičar, B. (2015). Slovnični pristop k vizualni komunikaciji: vizualna analiza vojnih fotografij. V M. Smolej (ur.), Slovnica in slovar - aktualni jezikovni opis, Obdobja 34 (str. 801-810). Ljubljana: Znanstvena založba Filozofske fakultete.

Voršič, I. (2018). Prvi odzivi učiteljic in učiteljev. V N. Ulčnik (ur.), Slovenščina na dlani 1 (str. 89-91). Maribor: Univerzitetna založba Univerze. Pridobljeno s http://press.um.si/index.php/ump/catalog/book/341 


\section{E-LEARNING ENVIRONMENT »SLOVENŠČINA NA DLANI : CHALLENGES AND SOLUTIONS}

The paper describes three types of challenges that were detected in teaching Slovene as a mother tongue at schools. First, a number of orthographic and grammatic mistakes can be detected in pupils' writings (see Kosem et al., 2012; Križaj in Bešter Turk, 2018; Gomboc, 2019). Second, low phraseological literacy was noticed and the pupils often have problems understanding phrasemes (Voršič, 2018). Third, the challenges of communicative competence were addressed, referring to production and interpretation of different written, spoken as well as multimedia genres, as only appropriate genre literacy enables efficient use of different genres (Nidorfer Šiškovič, 2013). To address these challenges, we have developed a complex e-learning environment for improving writing and communication skills of Slovene pupils - "Slovenščina na dlani”. The developed environment is divided into four general topics - orthography, grammar, phrasemes and texts. Each topic covers a number of subtopics, and for each sub-topic a number of exercises is available, along with explanations. We have used the most up-to-date language technologies and programming solutions in order to automatise the e-environment. The user's knowledge is automatically evaluated, and based on this $\mathrm{s} / \mathrm{he}$ is automatically guided through the environment in a way to improve her/his writing and communication skills. The e-environment has also a special user interface for teachers which enables easy way to assign tasks as well as to track the performance of each pupil individually or a group of pupils as a whole. The gamification and professional graphic design fulfil the user experience. The "Slovenščina na dlani" will be freely available at https://slo-na-dlani.si from September 2021 on.

Keywords: learning Slovene, computer assisted language learning, e-learning

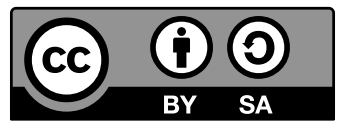

To delo je ponujeno pod licenco Creative Commons: Priznanje avtorstva-Deljenje pod enakimi pogoji 4.o Mednarodna. / This work is licensed under the Creative Commons Attribution-ShareAlike 4.0 International. 